Fischl Vilmos ${ }^{1}$

\title{
The Opportunities of Hungary for Dialogue with North Africa and the Middle East, with Particular Regard to the Persecuted Christians
}

\section{Magyarország párbeszéd-lehetőségei Észak-Afrikával és a Közel-Kelettel, különös tekintettel az üldözött keresztényekre}

\begin{abstract}
In the following study, the author examines how Hungary, as part of the European Union, builds and seeks switching points with the Arab world, bearing in mind the conflicts in the emerging Middle East and North African countries. It focuses on the possibility of dialogue, with particular regard to diplomatic negotiations and humanitarian aid. It also examines whether Hungary has a special role to play in this process or whether the relationship with the EU and the Arab world will be stabilised and shifted in the direction of reconciliation.
\end{abstract}

Keywords: conflicts, dialogue, Arabic world, Middle East, North Africa, persecuted Christians

\section{Absztrakt}

A szerzö azt vizsgálja, hogy Magyarország, az Európai Unió részeként, milyen módon épít és keres kapcsolódó pontokat az arab világgal, a felmerülő Közel Keleti és Észak Afrikai országokon belüli konfliktusokat is szem elött tartva. A párbeszéd lehetöségére 
helyezi a hangsúlyt, különös tekintettel a diplomáciai tárgyalásokra és a humanitárius segítségnyújtásra. Vizsgálja azt is, hogy Magyarországnak ebben a folyamatban van-e, vagy lehet-e speciális szerepe, hogy az EU és az arab világgal a kapcsolat stabilizálódjon, illetve ezekben az országokban a megbékélés irányába lépések történjenek.

Kulcsszavak: konfliktusok, párbeszéd, arab világ, Közel-Kelet, Észak-Afrika, üldözött keresztények

\section{Starting Point}

In my analysis I should like to focus on the opportunities for the European Union, of which Hungary is also a part, to seek and build links with North African, Middle Eastern and Asian Arabic countries. I should like to place great emphasis on the opportunities for dialogue, with particular regard to diplomatic negotiations. In addition, I will examine if Hungary has or can have a special role in the EU and in the North African, Middle Eastern and Asian Arabic countries so that the relationships could be stabilised in these countries and steps could be taken towards reconciliation. From the point of view of migration policy, the interests of the EU and Hungary differ. The EU lays stress primarily on inclusion, whereas Hungary favours assistance tailored to the local conditions of a given country.

\section{Islamic Modernism Following a Western Pattern}

In the course of history, it was the Napoleonic expansion at the end of the $18^{\text {th }}$ century that first turned the attention to the underdevelopment of North Africa (and the Middle East in a broader sense). This resulted in an almost immediate introduction of reforms in the region under the auspices of the Ottoman Empire. Moreover, at the same time, contemporary theoreticians started to find answers to the problems.

In the $19^{\text {th }}$ century, Jamal al-Dín al-Afghání (1839-1897) and Muhammad Abduh (1845-1905) were the fathers of the local reform movements, i.e. both of the Islamic modernism decisive in the $19^{\text {th }}$ century and in the first half of the $20^{\text {th }}$ century and of the Islamic fundamentalism starting in the second half of the $20^{\text {th }}$ century. According to the teachings of Afgháni and Abduh, the expected breakthrough could be realised by applying the European model, with due consideration, to the local circumstances. This kind of 'modern' thinking seemed to find its followers.

For the first generation of reform movements, i.e. Islamic modernism, it was the West which was set as an absolute example. This period saw the flourishment of the Arabic nationalisms, as well as the Arabic unification struggles. According to the premise of the modernisation theory, parallel with the development (industrialisation, urbanisation etc.), western institutions are also emerging in the given country and democracy becomes a general rule of the game. Because, according to the modernisation theory, by attaining a medium level of income, the economic 
prerequisites of democratic rearrangement are achieved. ${ }^{2}$ As a matter of fact, coinciding with this, there was also an opposition in the Arabic world against the West. Possibly the most famous grouping based on Islamic fundamentalism, the Muslim Brotherhood movement, was founded in Egypt in 1928 by Sayyid Qutb and Ahmad Hassan al-Banná. As its leading theoreticians, they have had a great impact on the present history of North Africa. They both criticised the West and aimed for the Islamisation of the political system and the society. ${ }^{3}$ The turnaround in the relationship to the West, however, was triggered by the 6-day war in 1967 when Israel completely defeated three Muslim countries: Egypt, Syria, and Jordan. This made apparent the contradictions hidden in the uncritical copying of Western patterns. The attempt to transplant nationalism, capitalism, and socialism (and other Western achievements) ended in a failure.

From the end of the 1960s, a second-generation reform movement set out: Islamic fundamentalism, whose most important objective is to reintegrate religion into politics; the fundamental pillar being that Islam can be the only solution to problems. It has since been proven that this line has not achieved the desired effects in the region, either.

\section{Description of the Situation}

For Europe - and for Hungary - North Africa has an unquestionable significance from the point of view of security policy, economy (market opportunity and raw material exporter), and tourism. In today's world of globalisation, conflicts, which earlier seemed to happen in a distant region, now have become close and could have an impact on our region. From a security policy perspective, it gives cause for concern that in the Madrid attack of March 11, 2004 some of the perpetrators were identified as people from the Maghreb area.

Is that region really the hotbed of terrorism? Is it true that the local dictators trample on human rights everywhere? Is there no hope for introducing democratic institutions? In the following, I seek to answer these questions.

From an economic and touristic aspect, the Middle East is a similarly important partner of the EU and of Hungary. Israel has an outstanding geopolitical role here, so, it is by far not indifferent what the leadership is like in the surrounding Arabic countries.

Concerning the Asian Arabic countries, we can speak about economic rather than touristic relations - the only exception being the United Arab Emirates.

I separate economic and touristic relations for security policy reasons, since in economic relations 'only' business people are involved who live in a country for several years - in a fortunate case with their families. But, in countries with touristic relations, the EU has to face a much greater hazard when a civil war breaks out as a relatively higher number of its citizens stay there. We should not forget about

Csicsmann László: Iszlám és modernizáció a Közel-Keleten. Az államiság eltérő modelljei, in: Csicsmann László (ed.): A Közel-Kelet demokratizálódásának esélyei a 21. században, Aula, Budapest, 2010, 90. www.grotius.hu/doc/pub/ SOMRRX/2010_91_iszlám\%20és\%20modernizáció.pdf (Downloaded: 16.02.2019.)

3 Benke József: Az arabok története, Alexandra, Budapest, 1997, 381. 
cultural relations either. A number of European countries have bilateral agreements on education and culture with a number of countries from the Arabic world. Hungary has a traditionally good relationship with Egypt through e.g. the Cairo-based Office of the Hungarian Cultural Counsellor. We have to re-evaluate our opportunities with regard to the present crisis situation. From this time on, Libya will never be the same country as before, and the same applies to Tunisia and/or Egypt. The Gulf War changed Kuwait, too, in 1991. The Kuwaiti emirate re-evaluated itself and the losses made the leadership think over things.

Pope Francis went on an official visit to Abu Dhabi on the first week of February 2019. ${ }^{4}$ On two major occasions during his three-day visit in the United Arab Emirates, he called his believers' attention to promote the dialogue between religions, to strengthen the Muslim-Christian relationships, and to follow Jesus' teaching. The Head of the Catholic Church did not call for only the promotion of dialogue; he cannot forget about the millions of Christians driven away from the region either. Pope Francis sought to emphasise the need for the inter-religious dialogue to avert international conflicts by evoking Jesus' Sermon on the Mount. On the last day of his three-day visit in the United Arab Emirates, the leader of the Catholic Church celebrated an open-air mass for 135 thousand people in the biggest stadium of Abu-Dhabi, the capital of the country situated on the Arab Peninsula.

Out of the 9.5 million inhabitants of the Sunni Arabic monarchy, some 90 percent are guest workers. About 2.5 million of them are Catholics mostly coming from the Philippines and India. Pope Francis apparently addressed primarily them when he spoke about the obvious difficulties of living far away from home, missing the affection of the loved ones and perhaps also feeling uncertainty about the future. ${ }^{5}$

\section{Demonstrations and Their Aftermath - What is to Come?}

The demonstrations started in December 2010 in Tunisia and spread from there to Egypt. We have heard about similar actions in Jordan, Yemen, Sudan, and Algeria. From this point of view, Egypt requires particular attention as it has the biggest population and the greatest cultural radiance among the Arabic countries. Its geostrategic position is very important, moreover, it is the most important Arabic military partner of the United States.

The question is what the main cause of this process was. The above written could partly give an answer, but there is also something else in the background. In general, we can mention the social and economic conditions characteristic of the countries concerned. Both in Tunisia and Egypt there is a very high unemployment rate. In Tunisia, it is officially 14.1 percent, but according to non-official data it is 24-25 percent. In Egypt, officially 10 percent of the active population is unemployed, but

\footnotetext{
Pope Francis celebrated Holy Mass in Abu Dhabi: May your communities be oases of peace. http://press.vatican.va/ content/salastampa/en/bollettino/pubblico/2019/02/05/190205b.html (Downloaded: 16.02.2019.)

5 Pope Francis holds first Papal Mass in Abu Dhabi https://www.aljazeera.com/news/2019/02/pope-francis-holdspapal-mass-abu-dhabi-190205065039040.html (Downloaded 30. 03. 2019.)
} 
actually there are many more jobseekers. It is especially important to mention that half of the soon 100-million Egyptian population lives near or below the poverty line, and there is frequent news about corruption. It is also a rather severe problem that many university graduates are unable to find a livelihood. The chain of the Tunisian events was triggered by a young man's suicide, committed in utter despair on December 17, 2010, leading to the fall of President Ben Ali on January 14, 2011.

In these societies, the political systems have a very narrow playing field, which also necessitates change. We can, though, detect significant differences between the events and their antecedents taken (and now taking) place in the two countries. While in Tunisia the Islamic powers were "decapitated", the most influential Islamic grouping in Egypt enjoyed semi-legal status and the support of a good part of the population.

In addition, there are substantial differences between the armies of the two countries. Tunisia maintains an armed force of 36 thousand, of which land forces are not more than 30 thousand. The number of security forces is many times the number of the army, which had not been too intensely developed in the past years. Contrary to this, Egypt has the strongest army in the region (at least in Arabic relations) consisting of 468 thousand people, and the number of land forces is above 340 thousand. Furthermore, the strength of internal security forces is also significant.

On February 11, 2011, President Mubarak resigned, and the power was taken over temporarily, for the presidential election process (for half a year), by the army. In July 2013, Commander-in-Chief el-Sisi became the leader of the country, who, with the help of the army, took the power away from the Islamists who had won the elections. ${ }^{6}$ Six weeks after the military takeover, the security forces crushed the sit-down strike of the supporters of the Muslim Brotherhood, then banned the whole Islamist opposition and jailed many of its leaders. Later on, the reckoning was extended to other groups of the opposition.

In Libya there are several opposition groupings. The past haunts, as Gaddafi had started in 1969 from Benghazi not far from the Egyptian border, and now demonstrations started at the same place. The moves got so intense as to disrupt the unity of the Libyan leaders and many soldiers started to support the rebels. At present, there are two governments in Libya, one in Benghazi, and one in Tripoli. International organisations acknowledge the Tripoli Government. There have been several efforts under international pressure to harmonise the two governments with not much success for the time being. Negotiations between the two governments have been being promoted by the UNO since 2015, with more or less success. The goal is the establishment of a temporary united government. ${ }^{7}$

6 Kiábrándultság és megélhetési gondok - Egyiptom öt évvel a forradalom után, 2016. https://hu.euronews.com/2016/01/25/ kiabrandultsag-es-megelhetesi-gondok-egyiptom-ot-evvel-a-forradalom-utan (Downloaded: 16.02.2019.)

Gugán Dániel: Líbia - az „elfelejtett polgárháború” és annak migrációs vetülete, Nemzet és Biztonság, 9 (2016/5) 7. www.nemzetesbiztonsag.hu/cikkek/nb_2016_5_03_gugan_daniel_-_libia-az_elfelejtett_polgarhaboru_es_annak_migracios_vetulete.pdf (Downloaded:16.02.2019.) 


\section{Possibilities of Dialogue with Arabic Countries}

The question is raised: how should the EU and Hungary relate to the Arabic countries? The EU, and particularly Italy, gets a remarkable amount of oil from Libya. This means that 32 percent of the oil produced in Libya flows to Italy. Libyan oil is of rather high quality - that is why the EU buys it. Oil prices have been getting higher and higher since the Libyan conflicts. For energy policy reasons, the EU wants to reduce its dependence on Russia, and, consequently is seeking other sources, as well. It is also in Hungary's interest to diversify its energy sources. Hungary had a traditionally good relationship with Libya. A lot of Hungarian doctors worked for decades in Libya and Kuwait. We must investigate what linking points are given to build new connections with Arabic countries - especially Tunisia, Egypt, and Libya - in the future. In Tunisia or Egypt, the old president is no longer in office. Gaddafi unfolded his theory concerning the role of political institutions in his so-called Green Book. He made it clear, for example, that modern political parties are unsuitable to vindicate the interests of the people. In the official name of the country there was jamahiriya ("immediate power of the masses"), but in fact the country was a special totalitarian republic. ${ }^{8}$ It shows similar traits with the earlier Arabic socialisms, inasmuch so that in its rhetoric it is left-wing and it builds on the immediate participation of the people.

Before the second half of the 1990s, the relationship between Libya and the West had not been perfect, but the decrease in oil prices resulted in a kind of consolidation, bridge-building on the part of Gaddafi, and, as a result, in May 2010 Libya was struck off the list of countries supporting terrorism. After the death of Gaddafi, Libya would not be the same as it had been for 41 years.

The EU needs oil. So, the question is what shall we do when a new Libyan government is formed which may put fundamentalist thinking more in the front than before? In my view, Europe should show a picture of stability. Speaking about Europe, we use the word "West" when we make comparisons with Islam. And under the term "West", we mean not only Europe and the United States, but also Christianity. The Islamic Arabic world is populated primarily by Muslims. Actually, there are countries where there are a number of Christians e.g. Egypt, Jordan, Syria or Algeria. The interreligious dialogue now seems to have failed to deliver on its hopes. When speaking about new dialogue, we cannot omit religion. In the Islamic thinking, Christians belong to the "people of the Book". This shows a kind of respect on their part. Many think that they must approach the Arabic world as ideologically neutral. They are mistaken! When at a negotiation, a Christian person approaches an Arabic (Muslim) negotiating partner on the basis of the Christian value system, then the Muslim person behaves respectfully - similar to our behaviour towards him. In my opinion, we should not think like this: "As we need oil, we should do for the oil whatever, say, the new Libyan government asks us to do." This way of thinking does not lead forward. On the contrary, it is doomed to fail. Countries rich in oil, e.g. Libya, do not give oil out of love, but for money, much money. If they need the money and the EU needs the oil, then it can lead to correct and balanced working and economic relations. Though

8 Rostoványi Zsolt: Az iszlám a 21. század küszöbén, Aula, Budapest, 1998, 186 
Hungary is not a big country, it has had traditionally good relations with Arabic countries. What is the reason for that? I see one of the causes in the Hungarian way of thinking and in their reliable and high-level professional skills. In the Hungarian character, there is a kind of particular empathy, which can hardly be found in other nations. And it is noticed and esteemed by the Arabic people. The former communist countries of Central Europe can serve as models for the nations of North Africa and the Middle East in their struggle for democracy and freedom of opinion and expression, said NATO Secretary General at a Warsaw conference. ${ }^{9}$ So, I think, it is politics, economy, culture (education), health care, sports, and mutual respect for religious values through which we can connect to the Arabic world. Our future relations with the Arabic countries which want new governments and democracy should stand on these new foundations and should build these connections. We should not be afraid of religion, as religion and political functions are amalgamated in Islam - this is the essence of organic religion. It is no longer the case in Europe, and it seems strange to the Arabic world, but it is similarly strange to us that the people itself requires Shi'ite and Sunni leaders in the parliament and in the government.

There are a lot of questions that the West has not been able to make clear. One of them is, whether the NATO and EU forces should intervene in Libya or not. The NATO Secretary General has confirmed that the NATO will intervene militarily in Libya only by the authorisation of the UN and by strong local support. ${ }^{10}$ For the time being, it seems that the Libyans want to settle their future themselves, either from the part of the government or from the part of the rebelling people. I think that the will of the people is important and that they should be given the chance to try and settle their own lives. We have seen the results of the military interventions in Afghanistan and Iraq which sadly means that, since the 'end' of the war, more people have died than during the pre-war reign of the dictatorial government and during the war altogether. This is precisely why we have to be careful with such outer military interventions. Let us not forget that a negative concomitant of a war is, for all the precise weapons, that it takes a great toll on the civilian population. ${ }^{11}$

The people of the concerned Arabic countries and the international public are both eager to see what the future will bring after the civil wars.

\section{Migration Agreement in Progress}

The inner EU regulations of migration have significant historical antecedents. The European regulation of migration has continuously been on the agenda since the European Coal and Steel Community was established in 1951. At that time, 'migration' was understood as the free movement of labour force of the six founding states on

\footnotetext{
NATO Secretary General: Közép-Európa modellként szolgálhat Észak-Afrika számára, 2011. https://hvg.hu/vilag/20110317_NATO_fotitkar_eszak_afrika (Downloaded: 16.02.2019.)

10 Ibid.

11 Harai Dénes: Az erőszak kultusza és a civilizáció védelme. (A terrorizmus elleni küzdelem társadalmi, társadalomtudományi kérdései.) Manuscript, ZMNE, 2008, 7.
} 
the common labour market. With the acceptance of the Schengen Agreement ${ }^{12}$ in 1985, it has had a firm legal foundation. However, today, the term migration is more and more understood in the EU as the movement of non-EU (third-country) citizens from outside into the EU. Its most urgent point on the agenda today is the common European regulation of the reception of asylum-seekers. But its common European regulation is far from being properly elaborated. The Dublin Regulation of 1990 currently in force and the Dublin III Regulation ${ }^{13}$ aimed at reforming the previous one, defines the responsibility of the EU member states in the examination of the applications for asylum, but a comprehensive, single, all-European regulation for asylum seeking, which is in accordance with the international conventions, has not been established till this very day. The 2015 migration crisis abruptly brought this deficiency to the surface; making it an acute problem and turning on a kind of improvised 'fire-fighting' in the European legislature.

On November 12, 2015, at the end of the two-day summit in Malta, ${ }^{14} \mathrm{EU}$ officials announced that the Union will offer a deal to Turkey, according to which the EU gives +3 billion Euros to support the country's endeavours to keep the 2 million Syrian refugees 'local' and restrain them from migrating on further to the EU. After all, the deal was, with further allowances, accepted by Turkey. The agreement between the EU and Turkey came into effect on March 20, 2016, and it obliges Turkey to receive back migrants who arrive illegally from Turkey to Greece..$^{15}$ This agreement afforded some time to the EU since they succeeded in, even though temporarily, 'freezing' the Eastern Mediterranean migration route. But, the (temporary) 'solution' of the eastern route did not advance the position of Italy, which lies in the centre of the southern route - in fact, it worsened it. For the handling of the migration coming from North Africa across Libya, there have been no solution propositions similar to the Turkey deal. The border protection solutions of military character (Mare Nostrum, ${ }^{16}$ Triton $^{17}$ and the Sophia interventions) did not bring the expected results due to their limited capacity. A 'new migration agreement' aims at handling this situation. Its elaboration was initiated by Italy, mainly because of the high number of migrants going there from Libya. The short survey of the 'new migration agreement' is of key importance as it is intended to offer a long-term solution to the more and more severe migration crisis of the EU. It would replace the present policy of ad hoc agreements with a systematic regulation. This will be designated to create a legally stable and predictable environment for the EU member states and their citizens and for the migrants arriving from beyond the

12 European Commission: The Schengen area and cooperation, 2008. https://eur-lex.europa.eu/legal-content/EN/TXT /?uri=LEGISSUM:L33020 (Downloaded: 16.02.2019.)

13 European Council: Regulation (EU) No 604/2013 of the European Parliament and of the Council of 26 June 2013 https://eur-lex.europa.eu/legal-content/en/ALL/?uri=celex\%3A32013R0604 (Downloaded 16th February 2019.)

14 European Council: Valletta Summit on migration, 11-12/11/2015. www.consilium.europa.eu/en/meetings/international-summit/2015/11/11-12/ (Downloaded: 16.02.2019.)

15 Migration Policy Institute: The Paradox of the EU-Turkey Refugee Deal, Migration Policy Institute, 2016. www.migrationpolicy.org/news/paradox-eu-turkey-refugee-deal (Downloaded: 16.02.2019.)

16 Ministry of Defence of Italy: Mare Nostrum Operation, 2013. www.marina.difesa.it/EN/operations/Pagine/MareNostrum.aspx (Downloaded: 16.02.2019.)

17 ANSA News: Frontex Triton operation to 'support' Italy's Mare Nostrum, 2014. www.ansa.it/english/news/2014/10/16/ frontex-triton-operation-to-support-italys-mare-nostrum_ad334b2e-70ca-44ce-b037-4d461ec0d560.html (Downloaded: 16.02.2019.) 
borders and to steer the hard manageable migration situation into a regulated framework. The new compact (i.e. the Italian draft serving as the basis for negotiations ${ }^{18}$ ) basically outlines the steps (propositions) the EU plans to take in order to decrease the illegal migration from North Africa, and it clarifies what measures Europe expects of the region's countries (principally Libya) to take in exchange for the propositions. The EU propositions for the region's countries are as follows: new investment projects and the establishment of a new EU investment fund for the region's countries; the issuing of "EU-Africa bonds" in order to facilitate the African countries' access to the financial market with the help of the EIB and other European and international financial organisations; and an increased security cooperation in terms of border control, customs, justice and asylum, tallying with the international rules and the regional grouping of tasks (regionalisation) with consideration to its cross-border character.

The EU expectations from the countries in the region are as follows: a commitment to an effective border control and a decrease of the migrant flow. Hungary completely meets the border control requirements of the EU. To sum up, the EU - quasi externalising the problem - wants to get migration restrained by 'coaxing' the countries of origin into cooperation. In exchange for stricter border control, cooperation, and readmission of illegal migrants, Europe offers the provision of legal (circular) migration opportunities in addition to financial and technical aid for the development of border defence. A further important detail is that the possible success of the cooperation would be rewarded by the EU with economic development measures by way of new European investment projects and EU-Africa bonds, which would, in the long run, help stabilise the region's countries struggling at present with severe economic problems. In theory, the plan looks impressive, but the question is: as long as there is no stable and single central government in Libya, who will carry out the tasks of the compact pertaining to partner countries, and, in the absence of a strong and legitimate central power who could the EU start negotiations with? The method, which was more or less proven in the case of Turkey governed by strong hands, cannot work successfully in a country with such a deficient state system like Libya.

We can say that the establishment of a stable Libya (even if with considerable EU/NATO support) would be the prerequisite for the elimination of the Central Mediterranean migration crisis. For the lack of a strong central government, there is simply no entity in today's Libya which would be able to efficiently roll up the human trafficking network active in the country's territory. The establishment of Libyan unity, however, is a very sensitive and complex process for historical and social structural reasons. It can be supported from the outside, but it cannot be enforced. In the case of Libya, the prerequisite for the (at least partial) implementation of any migration agreement is the establishment of a stable government, so the negotiations on migration must be preceded by a programme of state-establishing character which aims at the stabilisation and capacity enhancement of the state system. A 'migration agreement' plan is now being outlined, but it seems premature from the EU, as it would expect Libya to take significant steps before the establishment of a capable

18 The Government of Italy: Migration Compact: Contribution to an EU strategy for external action on migration, s. a. www.governo.it/sites/governo.it/files/immigrazione_0.pdf (Downloaded: 16.02.2019.) 
subject, i.e. government. To recognise this is of key importance, not only for the EU, but also for the whole region, since a Somalia-like fallen state on the outskirts of Europe would bring disastrous consequences in the long run to both the EU and to the neighbouring countries of Libya alike. ${ }^{19}$

Both the culture and civilisation where the migrants and refugees come from are different from ours. A tribal society, be it the background of those arriving from Afghanistan or countries in the Middle East or in Northern Africa, makes it difficult or even impossible for these people to adapt to our Western type society and civilisation. Some of them will be successful in meeting the requirements of integration, some of them will fail to do so. ${ }^{20}$

The Churches play a big role in migration handling, like the Holy See. The Holy See is in connection with numbers of international organisations that are affected in handling migration crisis. Namely, with the United Nations High Commissioner for Refugees, with the Organization for Security and Co-operation in Europe (OSCE) and with the International Organization for Migration. The Apostolic Holy See became the full member of the latter in December, 2011 during the papacy of Benedict XVI. The International Organization for Migration had been in close relations with the Catholic Church before, especially with those Catholic organisations that took part in handling the migration crisis. ${ }^{21}$

\section{Helping Syrian Christians by the Hungarian Government's Programme Hungary Helps}

Hungary has financed the rebuilding of schools, hospitals, and houses in Iraq and Syria through the programme Hungary Helps. Hungary secures higher education opportunities in Hungarian universities for young Middle Eastern and African persecuted Christians. Through the Hungary Helps programme, with 505 million Forints (one Euro is about 320 Forint), Hungary supports a Syrian humanitarian initiative called Open Hospitals. ${ }^{22}$ The support of the Open Hospitals project is the newest one. In the Syrian cities which had suffered a lot, in Aleppo, Homs and Damascus we support hospitals, which care for the poorest. During the eight-year war in Syria, 54 percent of the health infrastructure was destroyed. It results in the fact that today, there are more people dying due to the lack of health infrastructure than in the war actions.

19 Gugán (2016): op. cit. 12.

20 Fischl, Vilmos: The Role of Churches in Hungary in Providing Pastoral Care and Humanitarian Help for Migrants, AARMS, $17(2018 / 2) 18$

21 Ujházi, Lóránd: Amendments to the Governance Structure of the Holy See and Canon Law during the European Migration Crisis, American Diplomacy, (2017/12) 1. http://americandiplomacy.web.unc.edu/2017/12/amendmentsto-the-governance-structure-of-the-holy-see-and-canon-law-during-the-european-migration-crisis/ (Downloaded: 16.02.2019.)

22 Azbej Tristan: A magyar kormány elsődleges feladata, hogy a magyar emberek boldogulását segítse, 2019. www echotv.hu/hirek/2019/01/23/azbej-tristan-a-magyar-kormany-elsodleges-feladata-hogy-segitse-a-magyar-emberekboldogulasat (Downloaded: 16.02.2019.) 
It is in the quantifiable material interest of Hungarian and European people alike to continue a proportionate humanitarian policy beyond the borders of the country and the continent. For this reason, Hungary undertook the help of the Syrian Christians by the programme Hungary Helps. Supporting e.g. hospitals through the Syrian churches also means that the Hungarian Government helps all the Syrian people, because hospitals are to be used not only by Christians, but also by Muslims.

The Hungary Helps programme serves as a framework for all international humanitarian activities Hungary undertakes in order to help all people in need in the developing countries and in crisis zones. One of its (though not exclusive) priorities is the protection of persecuted Christians. The reason for that is threefold: humanitarian, migration political and identity-based. The most important of the three is the first one: the Hungarian Government has recognised that the persecution of Christians is one of the most severe humanitarian tragedies of our time. Some 70 percent of religious persecutions are targeted at Christians. Still, it does not receive enough attention in international politics, diplomacy, or in humanitarian programmes. According to statistics, there are at least 80 countries where there are persecutions of Christians, but we know only about a few.

Indeed, there are at least 80 countries where Christians suffer genocide-like persecutions or other atrocities. They are severely discriminated and their human rights, civil liberties, freedom of religion, and freedom of conscience are drastically restricted. It concerns 215 million Christians. According to estimates, the number in Syria dropped to less than a half of what it was (from 2 million to 800 thousand), in Iraq it dropped to one-fifth (from 1.5 million to 300 thousand). ${ }^{23}$ The Islamic State aimed at abolishing Christian communities from the Middle East. ISIS did not manage to do so, but now migration is taking young people who would mean the future. There is a Hungarian scholarship programme providing European-level training to young people with the aim that they should return to their original communities. There are about 170 students in Hungary training for professions which will be useful in their countries. For instance, Iraqi students study to become engineers in the hydrocarbon industry at Miskolc University. The provision of admission is a church letter of recommendation to confirm their commitment to their community and homeland. The Hungarian donations are launched from Hungary and arrive at the local churches without any intermediate stations; they are sent either directly by the treasury or by Hungarian charity organisations which help accomplish a project locally. With their steady presence, the Hungarian Maltese Charity Service in Syria and the Hungarian Interchurch Aid in Iraq are our important partners. ${ }^{24}$

What can churches do in Hungary? The Church has to perform its task further on in the present migration situation in Europe. Migration poses a real challenge for Christian communities. It challenges them to answer the question how much they are able to receive and handle differences. To receive means to love, to take people seriously, to facilitate everybody in being themselves, and to not feel threatened

\footnotetext{
23 Magyarok az üldözött keresztényekért, 2018. https://kepmas.hu/nemzeti-kuldetesunk-az-uldozott-keresztenyeksegitese (Downloaded: 16.02.2019.)

24 Ibid.
} 
because of their dissimilarity. The Church has to act in solidarity, as it is the mission of the Church. The Church runs a range of institutions to support the refugees arriving at the borders of Europe. It does not want to replace the state, but it has to react to human suffering. However, it must also be acknowledged that every migration movement must take place within legal boundaries or else it threatens public order. ${ }^{25}$

\section{Bibliography}

ANSA News: Frontex Triton operation to 'support' Italy's Mare Nostrum, 2014. www.ansa.it/english/news/2014/10/16/frontex-triton-operation-to-support-italys-mare-nostrum_ad334b2e-70ca-44ce-b037-4d461ec0d560.html (Downloaded: 16.02.2019.)

Anwar, Musztafa: Az iszlám, Kultúra és közösség, 6 (2001/4 - 2002/1) 89-97.

Armstrong, Karen: Az iszlám világ nyugati szemmel, Európa, Budapest, 1998.

Azbej Tristan: A magyar kormány elsődleges feladata, hogy a magyar emberek boldogulását segítse, 2019. www.echotv.hu/hirek/2019/01/23/azbej-tristan-a-magyar-kormany-elsodleges-feladata-hogy-segitse-a-magyar-emberek-boldogulasat (Downloaded: 16.02.2019.)

Bar, Shmuel: Az iszlám terrorizmus vallási gyökerei, 2004. http://cikkek.soti.ca/religious-sources-of-islamic-terrorism.html (Downloaded: 16.02.2019.)

Benke József: Az arabok története, Alexandra, Budapest, 1997.

Brett, Michael - Forman, Werner: A mórok - Az iszlám kultúra Nyugaton, Gondolat, Budapest, 1985.

Cahen, Claude: Az iszlám a kezdetektől az oszmán birodalom létrejöttéig, Gondolat, Budapest, 1989.

Csicsmann László: Iszlám és modernizáció a Közel-Keleten. Az államiság eltérő modelljei, in: Csicsmann László (ed.): A Közel-Kelet Demokratizálódásának esélyei a 21. században, Aula, Budapest, 2010, 95-142. www.grotius.hu/doc/pub/ SOMRRX/2010_91_iszlám\%20és\%20modernizáció.pdf (Downloaded: 16.02.2019.)

Detlef, Pollack: Vallás és modernitás: vallásszociológiai modellek, Lelkipásztor: Evangélikus lelkészi szakfolyóirat, 83 (2008/1) 2-13.

European Commission: The Schengen area and cooperation, 2008. https://eurlex.europa.eu/legal-content/EN/TXT/?uri=LEGISSUM:I33020 (Downloaded: 16.02.2019.)

European Council: Regulation (EU) No 604/2013 of the European Parliament and of the Council of 26 June 2013. https://eur-lex.europa.eu/legal-content/en/ ALL/?uri=celex\%3A32013R0604 (Downloaded: 16.02.2019.)

European Council: Valletta Summit on migration, 11-12/11/2015. www.consilium.europa. eu/en/meetings/international-summit/2015/11/11-12/ (Downloaded: 16.02.2019.)

25 Fischl Vilmos: A civil szervezetek és egyházak szerepe, különös tekintettel a protestáns egyházakra, in: Orbán Balázs (ed.), Budapest-jelentés a keresztényüldözésről, Emberi Erőforrások Minisztériuma, Budapest, 2017, 192. 
Fischl Vilmos: A civil szervezetek és egyházak szerepe, különös tekintettel a protestáns egyházakra, in: Orbán Balázs (ed.), Budapest-jelentés a keresztényüldözésről, Emberi Erőforrások Minisztériuma, Budapest, 2017, 185-194.

Fischl, Vilmos: The Role of Churches in Hungary in Providing Pastoral Care and Humanitarian Help for Migrants, AARMS, 17 (2018/2) 17-28.

Goldzicher Ignác: Az iszlám, Magvető, Budapest, 1980.

Goldzicher Ignác: Az iszlám kultúrája I-II, Gondolat, Budapest, 1981.

Gugán Dániel: Líbia - az „elfelejtett polgárháború” és annak migrációs vetülete, Nemzet és Biztonság, 9 (2016/5) 3-13. www.nemzetesbiztonsag.hu/cikkek/ nb_2016_5_03_gugan_daniel_-_libia-az_elfelejtett_polgarhaboru_es_annak_migracios_vetulete.pdf (Downloaded: 16.02.2019.)

Harai Dénes: Az erőszak kultusza és a civilizáció védelme. (A terrorizmus elleni küzdelem társadalmi, társadalomtudományi kérdései.) Manuscript, ZMNE, 2008, 1-9.

Gülen, M. Fethullah: Az igazi iszlámban nem létezik terrorizmus, 25 September 2007. https://fgulen.com/hu/alkotasok/terror-hu/28075-az-igazi-iszlamban-nem-letezik-terrorizmus (Downloaded: 16.02.2019.)

Kiábrándultság és megélhetési gondok - Egyiptom öt évvel a forradalom után, 2016. https://hu.euronews.com/2016/01/25/kiabrandultsag-es-megelhetesi-gondok-egyiptom-ot-evvel-a-forradalom-utan (Downloaded: 16.02.2019.)

Kis-Benedek József: Az iszlám terrorizmus napjainkban. 2006. március 23.

Magyarok az üldözött keresztényekért, 2018. https://kepmas.hu/nemzeti-kuldetesunk-az-uldozott-keresztenyek-segitese (Downloaded: 16.02.2019.)

M. Amir, Ali: Islam, Jihad and Terrorism. Jihad: one of the most misunderstood concepts in Islam, s. a. http://aboutjihad.com/terrorism/islam_jihad_terrorism.php (Downloaded: 16.02.2019.)

Migration Policy Institute: The Paradox of the EU-Turkey Refugee Deal, Migration Policy Institute, 2016. www.migrationpolicy.org/news/paradox-eu-turkey-refugee-deal (Downloaded: 16.02.2019.)

Ministry of Defence of Italy: Mare Nostrum Operation, 2013. www.marina.difesa.it/ EN/operations/Pagine/MareNostrum.aspx (Downloaded: 16.02.2019.)

NATO Secretary General: Közép-Európa modellként szolgálhat Észak-Afrika számára, 2011. https://hvg.hu/vilag/20110317_NATO_fotitkar_eszak_afrika (Downloaded: 16.02.2019.)

Oszama bin Laden, s. a. http://index.hu/kulfold/oszama (Downloaded: 16.02.2019.)

Pope Francis: Pope Francis holds first Papal Mass in Abu Dhabi, 2019. www.aljazeera.com/ news/2019/02/pope-francis-holds-papal-mass-abu-dhabi-190205065039040. html (Downloaded 30. 03. 2019.)

Pope Francis celebrated Holy Mass in Abu Dhabi: May your communities be oases of peace, 2019. http://press.vatican.va/content/salastampa/en/bollettino/pubblico/2019/02/05/190205b.html (Downloaded: 16.02.2019.) DOI: https://doi. org/10.1055/s-0039-1678636

Rogers, Michael: A hódító iszlám, Helikon, Budapest, 1987.

Rostoványi Zsolt: Mit kell tudni az iszlámról? Kossuth, Budapest, 1983.

Rostoványi Zsolt: Az iszlám a 21. század küszöbén, Aula, Budapest, 1998. 
Simon Róbert: Korán - A Korán világa. Helikon, Budapest, 1994.

The Government of Italy: Migration Compact: Contribution to an EU strategy for external action on migration, s. a. www.governo.it/sites/governo.it/files/immigrazione_0.pdf (Downloaded: 16.02.2019.)

Ujházi, Lóránd: Amendments to the Governance Structure of the Holy See and Canon Law during the European Migration Crisis, American Diplomacy, (2017/12) 1. http:// americandiplomacy.web.unc.edu/2017/12/amendments-to-the-governancestructure-of-the-holy-see-and-canon-law-during-the-european-migration-crisis (Downloaded: 16.02.2019.) 